\title{
РЕФЛЕКСІЙНО-ОЦІНЮВАЛЬНА КОМПЕТЕНЦІЯ ЯК СКЛАДНИК ПРОФЕСІЙНОЇ КОМПЕТЕНТНОСТІ МАЙБУТНІХ ЛІКАРІВ
}

\author{
Лобач Н. В. \\ кандидат педагогічних наук, \\ старший викладач кафедри медичної інформатики та медичної і біологічної фізики \\ Українська медична стоматологічна академія \\ вул. Шевченка, 23, Полтава, Украӥна \\ orcid.org/0000-0002-3795-7864 \\ lobach_n@bigmir.net
}

Саєнко М. С.

викладач кафедри медичної інформатики та медичної і біологічної фізики

Українська медична стоматологічна академія

вул. Шевченка, 23, Полтава, Україна

orcid.org/0000-0001-6732-9239

saenko_marina@rambler.ru

\section{Сілкова О. В.}

кандидат педагогічних наук, доиент, доиент кафедри медичної інформатики та медичної і біологічної фізики

Украӥнська медична стоматологічна академія

вул. Шевченка, 23, Полтава, Україна

orcid.org/0000-0002-2605-204X

silkova@rambler.ru

\author{
Ключові слова: професійна \\ компетентність, рефлексійно- \\ оцінювальна компетениія, \\ рефлексія, оичінювання, \\ майбутній лікар.
}

Метою даної статті є обгрунтування поняття та сутності рефлексійнооцінювальної компетенції майбутніх лікарів та визначення її місця у їхній професійнійдіяльності. Для досягнення поставленої метипроведеноаналіз науково-педагогічної, психологічної літератури, який дав можливість побудувати логічно структуровану послідовність визначення поняття «рефлексійно-оцінювальна компетенція», доповнити та узагальнити поняття «рефлексія» й «оцінювання» у діяльності майбутніх лікарів. Визначено типи рефлексії (особистісна, інтелектуальна, комунікативна, кооперативна, регулятивна), функції (мотиваційна, прогностична, організаційна, комунікативна, смислотворча, корекційна), види рефлексії за спрямованістю дій (особистісної діяльності та професійної діяльності). Зазначено, що рефлексія є професійно важливою якістю особистості, що $\epsilon$ необхідним компонентом здійснення професійної діяльності лікаря для самоосвіти, саморозвитку фахівця, забезпечує іiі ефективність, уміння адекватно здійснювати оцінювання своєї діяльності, своїх можливостей, моральних якостей і вчинків. Установлено, що поняття «рефлексія» та «оцінювання» у деякому сенсі є тотожними, оскільки відбувається співвіднесення отриманих результатів із цілями діяльності. Зазначені поняття виступають стрижневим компонентом зрілості особистості під час оволодіння ключовими компетенціями. 3'ясовано, що відповідно до проаналізованих освітньо-професійних програм до компетентностей, які формуються у здобувачів закладів медичної освіти, належать ті, що містять елементи рефлексійно-оцінювальної компетенції, а саме: самопізнання, 
цілепокладання, аналіз власного досвіду, планування, коригування власних дій, самовдосконалення. На основі вищезазначеного ми зробили висновок, що рефлексійно-оцінювальна компетенція майбутніх лікарів це якість особистості, що дає змогу найбільш ефективно й адекватно здійснювати рефлексію та оцінювання своєї діяльності. Це сприяє розвитку і саморозвитку майбутнього лікаря, його творчому підходу до навчальної та професійної діяльності, досягненню їх максимальної ефективності та результативності.

\title{
REFLECTIVE AND EVALUATIVE COMPETENCE AS A COMPONENT OF PROFESSIONAL COMPETENCE OF FUTURE DOCTORS
}

\author{
Lobach N. V. \\ Candidate of Pedagogical Sciences, \\ Senior Lecturer at the Department of Medical Informatics and Medical and Biological Physics \\ Ukrainian Medical Stomatological Academy \\ Shevchenko str., 23, Poltava, Ukraine \\ orcid.org/0000-0002-3795-7864 \\ lobach_n@bigmir.net \\ Saenko M. S. \\ Lecturer at the Department of Medical Informatics and Medical and Biological Physics \\ Ukrainian Medical Stomatological Academy \\ Shevchenko str., 23, Poltava, Ukraine \\ orcid.org/0000-0001-6732-9239 \\ saenko_marina@rambler.ru \\ Silkova O. V. \\ Candidate of Pedagogical Sciences, Associate Professor, \\ Senior Lecturer at the Department of Medical Informatics and Medical and Biological Physics \\ Ukrainian Medical Stomatological Academy \\ Shevchenko str., 23, Poltava, Ukraine \\ orcid.org/0000-0002-2605-204X \\ silkova@rambler.ru
}

Key words: professional competence, reflective and evaluative competence, reflection, assessment, future doctor.
The purpose of this article is to define the concept and essence of the reflective-evaluative competence of future doctors and finding its place in their professional activities. To achieve this goal, an analysis of scientific, pedagogical, psychological literature was carried out, which made it possible to build a logically structured sequence for defining the concept of "reflective and evaluative competence". To supplement and generalize the concepts of "reflection" and "assessment" in the activities of future doctors. The types of reflection (personal, intellectual, communicative, cooperative, regulatory), functions (motivational, prognostic, organizational, communicative, meaningforming, corrective), types of reflection on the direction of actions (personal activity and professional activity) have been determined. It is noted that reflection is a professionally important personality trait, a necessary component for the implementation of a doctor's professional activity. For self-education, the self-development of a specialist ensures its effectiveness, the ability to assess adequately their activities, capabilities, moral qualities, and actions. It has 
been established that the concept of "reflection" and "evaluation" are identical because the results obtained are correlated with the goals of the activity. These concepts are the central component of personality maturity in mastering key competencies. It was found that according to the analyzed educational and professional programs of competence, which are formed in future doctors, there are elements of reflective and evaluative competence, namely: selfknowledge, goal-setting, analysis of one's own experience, planning, adjusting one's own actions, self-improvement. Therefore, based on all of the above, we concluded that future doctors' reflective and evaluative competence is a personality quality that allows the most effective and adequate reflection and evaluation of their activities. This contributes to the development and selfdevelopment of the future doctor, his creative approach to educational and professional activities, achieving their maximum efficiency and effectiveness.

Постановка проблеми. Якщо розглядати освіту 3 погляду компетентнісного підходу, то вона, перш за все, передбачає підготовку студентів до життя, надання їм можливості застосовувати на практиці ключові компетентності, закладені в освітній системі. Така спрямованість освіти висуває нові вимоги до професійних якостей викладача, а також до рівня підготовки студента - майбутнього лікаря. У контексті модернізації освіти інтегральним показником якості його підготовки слід розглядати професійну компетентність, яка характеризує вміння майбутнього фахівця використовувати в конкретній ситуації засвоєні знання, уміння та особистий досвід.

Під професійною компетентністю науковці розуміють таку здатність фахівця від початку своєї професійної діяльності, яка дає можливість успішно (на рівні певного стандарту) відповідати суспільним вимогам медичної професії. Це стає можливим завдяки ефективному i належному виконанню завдань лікарської діяльності у результаті демонстрації відповідних особистих якостей. Для цього варто мобілізувати релевантні знання, уміння, навички, емоції, орієнтуючись на власну внутрішню мотивацію, ставлення, моральні й етичні цінності та досвід, оцінюючи обмеження у своїх знаннях і вміннях та самоусвідомлюючи інші ресурси для їх компенсації [10].

На думку М. Саєнко [13], професійна компетентність майбутніх лікарів складається 3 когнітивного, мотиваційного та особистісного компонентів. Науковці $[7 ; 8 ; 10]$ до складу професійної компетентності майбутніх лікарів включають навчально-пізнавальний, інформаційно-комунікаційний, інформаційно-аналітичний, особистісний, комунікативний та соціально-ціннісний компоненти.

На нашу думку, до складу професійної компетентності майбутніх лікарів варто включити також рефлексійно-оцінювальну компетенцію. Вона дає можливість сформувати вміння аналізувати свою роботу, визначати, наскільки повно розв'язані поставленні завдання, аналізувати, що необхідно ще зробити для досягнення цілей. На основі проведення аналізу наукової літератури є можливість оцінити зазначені види діяльності у цілому, а також окремі діiі. Формування рефлексійнооцінювальної компетенції є тривалим, безперервним та систематичним процесом.

Проблему формування рефлексійно-оцінювального компоненту готовності студентів до науково-дослідної діяльності розглядали такі науковці, як О. Бескровний, С. Тернов, В.Фортуна, К. Василенко та ін.

Метою статті $\epsilon$ обгрунтування поняття та сутності рефлексійно-оцінювальної компетенції майбутніх лікарів та визначення її місця у їхній професійній діяльності.

Виклад основного матеріалу дослідження. Для детального розгляду сутності поняття «рефлексійно-оцінювальна компетенція майбутнього лікаря» варто звернутися до аналізу логічно структурованої послідовності «рефлексійна діяльність - оцінювальна діяльність - рефлексійно-оцінювальна діяльність». На нашу думку, це дає змогу розкрити поняття та сутність рефлексійно-оцінювальної компетенції студентів і визначити їі місце у професійній компетентності майбутніх лікарів.

У сучасних дослідженнях поняття «рефлексія» (від лат. reflexio - обернення назад, відображення, віддзеркалення) розуміється як процес самопізнання суб'єктом внутрішніх психічних актів та станів [12]. Аналіз науково-психологічної, філософської літератури, яка присвячена вивченню рефлексії, дає змогу визначити, що єдиного підходу до розуміння і вивчення феномена «рефлексія» немає. Проте на основі різних класифікацій можна впорядкувати деякі існуючі підходи. У роботах Л. Вигодського, В. Давидова, С. Рубінштейна поняття «рефлексія» розглядається як здатність людини до самоаналізу, осмислення i переосмислення своїх предметно-соціальних відносин із навколишнім світом і як необхідний складник розвиненого інтелекту людини [2, с. 17]. 
Ю. Кушеверська зазначає, що для того щоб розвити рефлексію на рівні самоаналізу, самооцінки, самоконтролю, саморегуляції i саморозвитку, необхідно починати 3 найпростіших рефлексивних якостей, таких як первинне самоспостереження та аналіз [6].

Л. Ладес детально досліджує самоконтроль і мотивацію до самооцінки, які вважає важливими аспектами процесу організації та реалізації рефлексійної діяльності, тому для формування навичок рефлексійної діяльності у процесі навчання науковець пропонує використовувати різні методи, за допомогою яких розвиваються самооцінка і самоконтроль [16].

Таким чином, у межах даного дослідження під поняттям «рефлексія» розумітимемо здатність особистості до самоаналізу й самооцінки, осмислення та переосмислення власних дій і відносин iз предметно-соціальним довкіллям.

Аналіз наукової літератури дав змогу визначити основні типи рефлексії:

- особистісна рефлексія - це така властивість свідомості, яка показує нам те, що всередині неї $є$ певна здатність або спосіб роботи даної системи, що дає змогу зрозуміти свій внутрішній світ за допомогою самооцінки своїх якостей і станів [15];

- інтелектуальна рефлексія - полягає у співвіднесенні власних дій і предметної ситуації, знання про об'єкт і шляхи дії з ним. Головним чинником iï розвитку є навчальна діяльність, у процесі якої той, хто навчається, досліджує підстави власних розумових дій у ситуації розв'язання навчальних завдань, а також виконання дій та їх оцінювання [9];

- комунікативна рефлексія - $\epsilon$ основою продуктивного міжособистісного спілкування, здатність пізнання людини іншою людиною, уявлення про ii внутрішній світ, усвідомлення індивідом того, як він сприймається партнером по спілкуванню. Цей вид рефлексії $є$ найважливішим складником ефективного спілкування [5];

- кооперативна рефлексія - забезпечує узгоджену спільну діяльність та об' єднання кількох суб' єктів для досягнення ними спільної мети [11];

- регулятивна рефлексія - забезпечує процеси самореалізації, саморозвитку особистісного і професійного самовизначення, організації власної професійної діяльності [14].

На основі проведеного дослідження можемо визначити основні функції рефлексії: мотиваційна (визначення спрямованості на результат); прогностична (проєктування i моделювання діяльності); організаційна (організація найбільш ефективних способів взаємодії у спільній діяльності); комунікативна (як умова продуктивного спілкування); смислотворча (формування у свідомості смислу їхньої власної діяльності); корек- ційна (спонукання до корегування, змін у взаємодії і діяльності).

Таким чином, рефлексія розглядається як принцип існування самосвідомості, універсальний механізм саморегуляції i саморозвитку. Спираючись на індивідуальну шкалу цінностей, рефлексія виявляється у пізнанні самого себе, осмисленні власних дій, розумінні сенсу міжособистісного спілкування, впливає на форми і способи пізнавальної і перетворюючої діяльності.

Розглядаючи види рефлексії за спрямованістю дій, науковці виділяють рефлексію особистісної діяльності та професійної діяльності [3].

Рефлексія особистісної діяльності - це усвідомлення самого себе як суб'єкта діяльності, що призводить до переосмислення всієї діяльності у цілому. Рефлексійна діяльність у майбутніх лікарів здійснюється у двох формах: за допомогою мотивації та самооцінки. Мотивація є спонукальним чинником до діяльності, а самооцінка - це основа для усвідомлення своїх сил та можливостей перед початком виконання завдань.

На думку О. Городиської, основними чинниками розвитку рефлексійної діяльності студентів $є$ : усвідомлення змісту навчального матеріалу, його основних ідей і положень; оволодіння раціональними прийомами обробки, систематизації змісту навчального матеріалу; знання вимог, що висуваються до якості засвоєного матеріалу [3, с. 29].

Ду Лян уважає, що рефлексія завжди звернена до особистісної діяльності студента і до самого студента як суб' єкта діяльності. Аналізуючи свою власну діяльність, студент акцентує увагу як на знаннях і результатах діяльності, так і на структурі самої діяльності, яка сприяє досягненню у подальшому прогнозованих результатів. Таким чином, особистісний аспект рефлексії у студентів сприяє побудові образів себе як лікаря під час виконання завдань професійного спрямування [4, с. 128 ].

Вивчаючи рефлексію у професійній діяльності лікаря, бачимо, що дане поняття розглядається як найважливіша робота щодо співвідношення себе до тих вимог, яких потребує вибрана професія. Розглядаючи практичну діяльність лікаря, слід відзначити, що рефлексія $є$ базовим складником у тих чи інших лікарських діях: складанні плану обстеження хворого з урахуванням необхідного i достатнього обсягу отриманих даних, оптимальної послідовності дій і операцій обстеження; зборі, аналізі й оцінці даних анамнезу; виборі і здійсненні методів обстеження, відповідних до даної патології та стану хворого; аналізі й оцінці даних клінічних, лабораторних та інструментальних методів обстеження; порівнянні отриманих суб' єктивних і об'єктивних даних з основними клінічними проявами хвороби; постановці й обгрунтуванні клінічного діагнозу на основі отриманих 
даних; проведенні диференціального діагнозу на основі порівняння із симптомами подібних захворювань; проведенні додаткових досліджень, консультацій із фахівцями; постановці остаточного клінічного діагнозу і плануванні лікувально-профілактичних дій.

Таким чином, рефлексія - це важлива якість особистості, яка $є$ необхідним компонентом для здійснення професійної діяльності, забезпечує іiі ефективність, уміння адекватно здійснювати оцінювання своєї діяльності, можливостей, моральних якостей і вчинків.

Розглядаючи поняття «оцінювання», науковці розділяють його на кількісне (оцінка набутих знань, умінь і навичок, що виражається у балах) та якісне (використання оціночних суджень, що містять характеристику діяльності, яка здійснюється людиною, виділення ії переваг та недоліків).

Ж. Болтачова [1, с. 12] вважає, що готовність до оціночної діяльності представлена як інтегративна якість особистості, що складається 3 основних структурних компонентів: мотиваційного (стійка спрямованість на самостійне вирішення завдань на оцінювання), когнітивний (містить знання узагальненої орієнтовної основи оцінювальної діяльності, принципів і методів оцінювання), діяльнісного (сукупність необхідних і достатніх умінь і етапів оцінювальної діяльності).

Таким чином, у рамках нашого дослідження розглядатимемо оцінювання як процес формування судження про цінності, ступінь, рівень певного об'єкта або явища, що містить кількісний і якісний аналіз. Рефлексія як особлива пізнавальна дія дає змогу уточнити свої знання, адекватно оцінити власні досягнення і можливості, зробити необхідні висновки щодо самовдосконалення. На нашу думку, поняття «рефлексія» та «оцінювання» у деякому сенсі є тотожними, оскільки відбувається співвіднесення отриманих результатів із цілями діяльності.

Отже, рефлективність і оцінювання виступають стрижневим компонентом зрілості особистості під час оволодіння ключовими компетенціями. До того ж вони є такими властивостями особистості, які дають змогу говорити про необхідність формування рефлексійно-оцінювальної компетенції у майбутнього лікаря. При цьому рефлексійно-оцінювальну компетентність можна віднести до складу як ключових компетенцій, які необхідні у навчальній діяльності, так і до базових компетенцій, які є важливими у професійній діяльності.

На основі аналізу освітньо-професійної програми, розробленої для студентів Української медичної стоматологічної академії, які навчаються за такими напрямами підготовки, як «Медицина» та «Стоматологія» другого (магістерського) рівня вищої освіти, нами визначено компетент- ності випускника закладу вищої медичної освіти. До таких, які містять рефлексійно-оцінювальні дії, належать: здатність до абстрактного мислення, аналізу та синтезу; знання та розуміння предметної сфери та розуміння професійної діяльності; уміння виявляти, ставити та вирішувати проблеми; здатність бути критичним і самокритичним; спроможність інтерпретувати результат лабораторних та інструментальних досліджень; знання та розуміння предметної галузі та розуміння професійної діяльності; здатність до адаптації та дії в новій ситуації; здатність приймати обгрунтовані рішення; працювати в команді; навички міжособистісної взаємодії; здатність до проведення аналізу діяльності лікаря, підрозділу, закладу охорони здоров'я, проведення заходів щодо забезпечення якості медичної допомоги і підвищення ефективності використання медичних ресурсів.

Таким чином, для оволодіння зазначеними компетентностями необхідно володіти рефлексійно-оцінювальною компетенцією, а саме: самопізнання, цілепокладання, аналіз власного досвіду, планування, коригування власних дій, самовдосконалення. Із боку викладача для формування рефлексійно-оцінювальної компетенції у майбутніх лікарів необхідно використовувати особистісно-орієнтований підхід до навчання. Він передбачає уміння організовувати суб'єктну активність студентів, створювати для цього спеціальні умови, звертатися до аналізу й оцінки способів, які спонукають їх до усвідомлення не лише результату, а й процесу навчальної роботи. У зв'язку із цим необхідно володіти прийомами, що стимулюватимуть рефлексію майбутніх лікарів.

Уміння планувати, проєктувати і здійснювати цілісний оцінювальний процес передбачає наявність уміння ставити цілі і визначати завдання своєї діяльності, співвідносити цілі і результати діяльності, усвідомлювати причини своїх невдач і успіхів, що передбачає високий рівень самопізнання, знання власних індивідуальних особливостей, а отже, сформованість рефлексійно-оцінювальної компетенції.

Таким чином, під рефлексійно-оцінювальною компетенцією ми розуміємо якість особистості, що дає змогу найбільш ефективно й адекватно здійснювати рефлексію та оцінювання своєї діяльності, що сприяє розвитку і саморозвитку майбутнього лікаря, його творчому підходу до навчальної та професійної діяльності, досягненню їх максимальної ефективності та результативності.

Висновки і перспективи подальших розробок у цьому напрямі. Серед перспективних напрямів подальшого дослідження на увагу заслуговує визначення компонентного складу та критеріїв сформованості рефлексійно-оцінювальної компетенції. 


\section{ЛІТЕРАТУРА}

1. Болтачева Ж.В. Формирование готовности студентов к оценочной деятельности в процессе изучения дисциплин гуманитарного цикла : автореф. дис. ... канд. пед. н. : 13.00.08. Саратов, 2007. 26 с.

2. Васильєва О.М. Роль рефлексії в саморозвитку майбутнього професіонала. Професійно-прикладні дидактики. 2016. № 2. С. 15-19.

3. Городиська О.М. Формування педагогічної рефлексії вчителя. Вісник НТУУ «КПІ». Філологія. Педагогіка. 2015. Вип. 6. С. 28-33.

4. Ду Лян. Самореалізація особистості студента у процесі позанавчальної музично-просвітницької діяльності. Науковий часопис Національного педагогічного університету імені М.П. Драгоманова. Серія 11: Соціальна робота. Соціальна педагогіка. 2017. Вип. 23. С. 25-30.

5. Кутішенко В.П. Ставицька С.О. Рефлексія як метаздібність до вибудовування цілісності життя та успішності спілкування майбутніх фахівців. Актуальні проблеми психологї̈. 2019. Вип. 15. С. 87-98.

6. Кушеверская Ю.В. Формирование рефлексийной компетентности студентов в образовательном процессе педагогического колледжа : автореф. дис. ... канд. пед. наук. Петрозаводск, 2007. 21 с.

7. Лобач Н.В. Формування інформаційно-аналітичної компетентності майбутніх лікарів в освітньому середовищі вищого медичного навчального закладу : автореф. дис. ... канд. пед. наук : 13.00.04. Полтава, 2016. $21 \mathrm{c.}$

8. Маркова А.К. Психология профессионализма. Москва, 1996. 308 с.

9. Мойсеєнко С.М. До поняття рефлексії в педагогічній діяльності. Актуальные научные исследования в современном мире. 2018. Вып. 10(42). Ч. 4. С. 68-71.

10. Мруга М.Р. Структурно-функціональна модель професійної компетентності майбутнього лікаря як основа діагностування його фахових якостей : автореф. дис. ... канд. пед. наук : 13.00.04. Київ, 2007. $20 \mathrm{c}$.

11. Носко Л.А. Рефлексія як особлива психічна реальність. Актуальні проблеми психології. 2015. Вип. 38. С. 351-360.

12. Петровский А.В., Ярошевский М.Г. Психологический словарь. Москва, 1990. 494 с.

13. Саєнко М.С. Зміст і структура професійної компетентності майбутніх лікарів. Наукові записки Тернопільського національного педагогічного університету імені Володимира Гнатюка. 2018. № 1. C. 83-89.

14. Фурман А.А. Психологія смисложиттєвого розвитку особистості : монографія. Тернопіль : ТНЕУ, 2017. $508 \mathrm{c}$.

15. Фурман В.А. Структурні компоненти особистісної рефлексії студентів технічного напрямку навчання. Вісник Національного авіаційного університету. Серія «Педагогіка, Психологія». 2013. № 4. C. 1-6.

16. Leonhard K.Lades. Impulsive consumption and refletive thought: Nudging ethical consumer behavior. Journal of Economic Psychology. 2014. Vol. 41. P. 114-128.

\section{REFERENCES}

1. Boltacheva Zh.V. (2007) Formyrovanye hotovnosty studentov $k$ otsenochnoi deiatelnosty $v$ protsesse yzuchenyia dystsyplyn humanytarnoho tsykla [Formation of students' readiness for assessment activities in the process of studying the disciplines of the humanities] (PhD Thesis), Saratov: Saratov State Vavilov Agrarian University.

2. Vasylieva O.M. (2016) Rol refleksii v samorozvytku maibutnoho profesionala [The role of reflection in the self-development of a future professional] Professional and Applied Didactics, no. 2, pp.15-19.

3. Horodyska O.M. (2015) Formuvannia pedahohichnoi refleksii vchytelia [Formation of teacher's pedagogical reflection] Bulletin of NTUU "KPI". Philology. Pedagogy. Vol. 6, pp. 28-33.

4. Du Lian (2017) Samorealizatsiia osobystosti studenta u protsesi pozanavchalnoi muzychno-prosvitnytskoi diialnosti [The self-realization of the student's personality in the process of extracurricular musical and educational activities]. Scientific journal of National Pedagogical Dragomanov University. Vol. 23, pp. 25-30.

5. Kutishenko V.P. Stavytska S.O. (2019) Refleksiia yak metazdibnist do vybudovuvannia tsilisnosti zhyttia ta uspishnosti spilkuvannia maibutnikh fakhivtsiv [Reflection as a meta-ability for building the integrity of life and the success of communication of future specialists] Actual problems of psychology: Collection of scientific works of the Institute of Psychology named after GS Kostyuk NAPS of Ukraine. Vol. 15, pp. 87-98.

6. Kusheverskaia Yu.V. (2007) Formyrovanye refleksyinoi kompetentnosty studentov v obrazovatelnom protsesse pedahohycheskoho kolledzha [Formation of reflective competence of students in the educational process of a pedagogical college] (PhD Thesis), Petrozavodsk: Karelian State Pedagogical Institute. 
7. Lobach N.V. (2016) Formuvannia informatsiino-analitychnoi kompetentnosti maibutnikh likariv $v$ osvitnomu seredovyshchi vyshchoho medychnoho navchalnoho zakladu [Forming of information and analytical competence of future doctors in educational environment of higher medical educational establishment] (PhD Thesis), Poltava: Poltava V.G. Korolenko National Pedagogical University.

8. Markova A.K. Psykholohyia professyonalyzma. [Psychology of professionalism]. Moscow: International Humanitarian Foundation «Knowledge». (in Russian).

9. Moiseienko S.M. (2018) Do poniattia refleksii v pedahohichnii diialnosti [To the concept of reflection in pedagogical activity] Actual trends of modern scientific research, Vol. 10 (42), no. 4, pp. 68-71.

10. Mruha M.R. (2007) Strukturno-funktsionalna model profesiinoi kompetentnosti maibutnoho likaria yak osnova diahnostuvannia yoho fakhovykh yakostei [Structural and functional model of the professional competence of a future doctor as the basis for diagnosing his professional qualities] (PhD Thesis), Kyiv: Bogomolets National Medical University.

11. Nosko L.A. (2015) Refleksiia yak osoblyva psykhichna realnist. [Reflection as a special psychic reality.]. Actual Problems of Psychology. Vol. 38, pp. 351-360.

12. Petrovskyi A.B. Yaroshevskyi M.H. (1990) Psykholohycheskyi slovar. [Psychological Dictionary]. Moscow: Politizdat (in Russian).

13. Saienko M.S. (2018) Zmist i struktura profesiinoi kompetentnosti maibutnikh likariv [Content and structure of professional competence of future doctors]. Scientific Issue Ternopil Volodymyr Hnatiuk National Pedagogical University. Vol. 1. pp. 83-89.

14. Furman A.A. (2017) Psykholohiia smyslozhyttievoho rozvytku osobystosti [Psychology of life-meaningful development of personality]. Ternopil: TNEU. (in Ukrainian)

15. Furman V.A. (2013) Strukturni komponenty osobystisnoi refleksii studentiv tekhnichnoho napriamku navchannia. [Structural components of special reflection of technical students]. Proceedings of the National Aviation University. Vol. 4, pp. 1-6.

16. Leonhard K.Lades. Impulsive consumption and refletive thought: Nudging ethical consumer behavior. Journal of Economic Psychology. 2014. Vol. 41, pp. 114-128. 